A SPECIAL ISSUE FOR THE $6^{\text {TH }}$ SCIENTIFIC INTERNATIONAL CONFERENCE

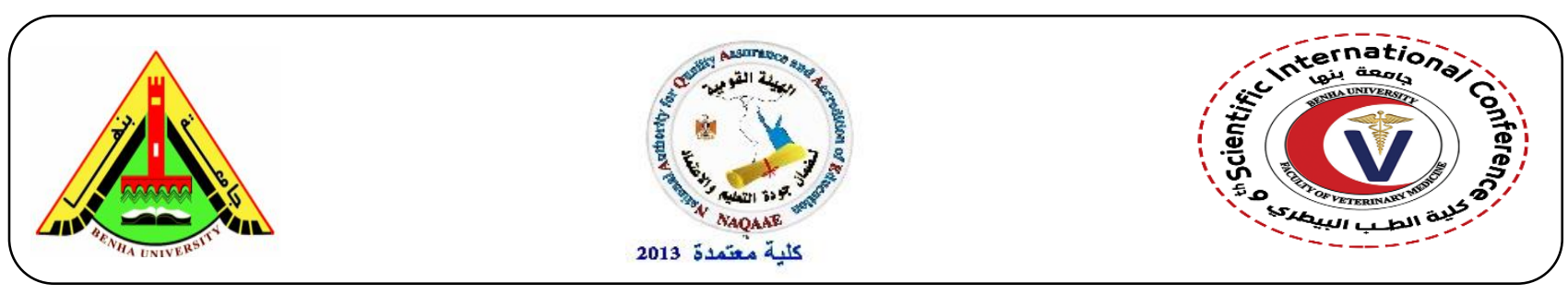

\title{
Food Poisoning Bacteria Contaminating Beef at Abattoir Level
}

\author{
${ }^{1}$ Hassan, M.A. and ${ }^{2}$ Reham Moawad \\ ${ }^{1}$ Food hygiene \& control Dep., Fac. Vet. Med. Benha Univ. \\ ${ }^{2}$ Vet. Medicine Directorate "Shibin El- Kom"
}

\section{A B S T R A C T}

It is very important to achieve the safety and sanitary quality of meat, so we should estimate the bacterial load in beef sample at abattoir level. The study was conducted on 90 beef samples $(25 \mathrm{~g}$ of each) collected from 3 abattoirs in menofia governorate statistically, the results of aerobic plate count (APC), Enterobacteriaceae count and Staphylococci count, were not significantly different $(\mathrm{P}>0.05)$ between the three slaughterhouses A, B and C. The prevalence of the Enteropathogenic $E$. coli isolated from the beef samples in A, B and C were $16.66 \%, 26.66 \%$, and $20 \%$, respectively. Serologically, the serotypes of E. coli were O26:H11, O114:H4, O172, O128: H172, O 125: H 21, O163:H2, O91: H21, O78, O124, O111:H2, and O158. The prevalence of Salmonella in the three abattoirs were $6.66 \%, 23.33 \%$, and $13.33 \%$, respectively, and the identified serotypes were Salmonella Infantis, Salmonella Typhimurium Salmonella Enteritidis, Salmonella Tsevie, Salmonella Kentucky, Salmonella Heidelberg, and Salmonella Tamale. Also, Staphylococcus aureus was isolated from $34.44 \%$ (31/90) beef samples, with the following percentages from the three abattoirs, $26.66 \%, 43.33 \%$, and $33.33 \%$, respectively. Conclusively, the results were higher than those recommended by Egyptian Organization of Standardization (EOS), therefore good slaughtering and hygienic practices recommended by general organization for veterinary services (GOVS) must be followed.

Keywords: beef, bacteriological profile, E. coli, salmonellae, S. aureus.

(http://www.bvmj.bu.edu.eg)

(BVMJ-34(2): 120-128, 2018)

\section{INTRODUCTION:}

The intact tissues of healthy slaughtered animals are mostly sterile, but the meat may be contaminated during slaughtering, handling, processing and storage from hands, workers, clothes, knives, hide, gut, fecal material on feet or from the environment.
Microbial contamination of the carcass results in spoilage of meat, reduced shelf-life of meat and public health hazards (Phillips et al.,2006) either due to presence of spoilage bacteria responsible for unfavorable changes or pathogenic bacteria leading to harmful effects 
as food infection or intoxication among consumers (Eley, 1992).

Fecal matter was a major source of contamination and could reach carcasses through direct deposition, as well as by indirect contact between contaminated and clean carcasses, equipment, workers, installations and air (Borch and Arinder ,2002).

The food borne pathogens are responsible to impose a substantial burden of infection in the developed countries, while the impact in case of developing countries is higher. It reduces markedly social and economic productivity of the countries. Amongst the food borne pathogens, E. coli, Salmonella and Staphylococcus aureus are the most common and frequent pathogens responsible for food poisoning and food related infections (Pires et al., 2012).

The aerobic plate count indicates the level of microorganisms in a product and provide general estimate of the quality, shelf life and post heat processing contamination (Maturin and Peeler, 1998).

Enterobacteriaceae are group of bacteria that is used to assess the general hygienic status of a food product (HPA, 2004). So, the object of the current study was to evaluate the bacteriological quality of beef at abattoir level.

\section{MATERIALS AND METHODS:}

\subsection{Samples:}

A total of 90 fresh beef samples $(25 \mathrm{~g}$ of each) were collected from 3 different abattoirs namely $\mathrm{A}, \mathrm{B}$ and $\mathrm{C}$ located in Menofia governorate. The samples were transferred in an ice box directly within an hour to the laboratory with a minimum delay for bacteriological examination.
2.2. Determination of $A P C$,

Enterobacteriaceae and total Staphylococci counts.

The technique recommended by (ICMSF, 1996) was carried out.

\subsection{Screening of Enteropathogenic E. coli:}

The $E$. coli strains in the meat samples were isolated using the method of the Bacteriological Analytical Manual (APHA, 2001) One $\mathrm{ml}$ of homogenized meat sample inoculated into MacConkey broth for enrichment of the E. coli strains, and then incubated at $37^{\circ} \mathrm{C}$ for 18 to $24 \mathrm{~h}$. The enriched cultures were streaked onto Eosin Methylene Blue (EMB) agar in two plates and incubated at $37{ }^{\circ} \mathrm{C}$ for $24 \mathrm{~h}$. Presumptive $E$. coli colonies on EMB plates, which were round and had a metallic-green color with a dark or purple center, were further confirmed by inoculating the colonies EMB plates and incubated at $44{ }^{\circ} \mathrm{C}$ for $24 \mathrm{~h}$. Then presumptive E. coli colonies picked up and kept in Semisolid nutrient agar for biochemical and serological identification.

$\begin{array}{clrr}\text { 2.4. Screening } & \text { of } & \text { salmonella } & \text { organism } \\ \text { according } & \text { to } & \text { ISO } & 6579: \\ \text { (2002) } & \text { protocol } & \text { (International }\end{array}$
Organization for Standardization (ISO) 2002), The homogenate specified for isolation of salmonella was incubated at $37^{\circ} \mathrm{C}$ for $22 \mathrm{~h}$ for pre-enrichment. After resuscitation, $0.1 \mathrm{~mL}$ was inoculated into $10 \mathrm{ml}$ RappaportVassiliadis medium and incubated at $42^{\circ} \mathrm{C}$ for $24 \mathrm{~h}$. After enrichment, a loopful of each enriched sample was streaked onto xylose lysine desoxycholate agar and incubated at $37^{\circ} \mathrm{C}$ for $24 \mathrm{~h}$. the purified suspected colonies were selected and streaked onto slope nutrient agar for biochemical and serological identification.

2.5. Screening of $S$. aureus according to (APHA, 2001): 
Accurately, $0.1 \mathrm{ml}$ from each of previously prepared serial dilutions was spread over duplicated plates of Baired Parker agar using a sterile glass spreader. The inoculated and control plates were incubated at $37^{\circ} \mathrm{C}$ for 48 hours. The developed colonies were enumerated, and the total Staphylococci count /g was calculated. Also, the colonies were picked up and purified on nutrient agar slopes for further identification. Films were prepared from a pure culture of the isolated microorganism stained with Gram's stain and then examined microscopically. Staphylococci appeared as Gram positive cocci resembling grape like clusters. The purified suspected colonies were picked up with a sterile loop for biochemical and serological identification.

\section{RESULTS:}

Table (1) indicated that the mean values of APC $(\mathrm{cfu} / \mathrm{cm} 2)$ of the tested beef samples in Shibin-Elkom, Ashmon and Menouf abattoirs were $1.33 \times 10^{7} \pm 5.64 \times 10^{6}, 1.85 \times$ $10^{7} \pm 5.14 \times 10^{6}$ and $1.29 \times 10^{7} \pm 3.85 \times 10^{6}$ respectively. On the other side, the mean values of total enterobacteriacae count $(\mathrm{cfu} / \mathrm{cm} 2)$ of the tested beef samples abattoirs were $1.15 \times$ $10^{4} \pm 2.93 \times 10^{3}, 1.49 \times 10^{4} \pm 3.74 \times 10^{3}$ and $1.80 \times 10^{4} \pm 5.15 \times 10^{3}$ respectively. Furthermore, total Staphylococci count $(\mathrm{cfu} / \mathrm{cm} 2)$ of the tested beef samples were 1.75 $\times 10^{4} \pm 4.91 \times 10^{3}, 2.19 \times 10^{4} \pm 5.82 \times 10^{3}$ and $2.31 \times 10^{4} \pm 5.74 \times 10^{3}$ respectively.

Table (2) showed that Enteropathogenic E. coli was serologically identified from the examined samples of beef as A, B and C. abattoir were $16.66 \% 26.66 \%$ and $20 \%$, respectively. To clarify, In a abattoir EPEC were $\mathrm{O}_{114} \mathrm{H}_{4}$ and $\mathrm{O}_{172}$ at percentage of $3.33 \%$ and $3.33 \%$, while EHEC was $\mathrm{O}_{26} \mathrm{H}_{11}$ at percentage of $6.66 \%$ finally ETEC was $\mathrm{O}_{128} \mathrm{H}_{172}$ at percentage of $3.33 \%$ (Table, 9). In B abattoir EPEC were $\mathrm{O}_{163} \mathrm{H}_{2}$ and $\mathrm{O}_{78}$ at percentage of $3.33 \%$ and $3.33 \%$, EHEC were $\mathrm{O}_{26} \mathrm{H}_{11}$ and $\mathrm{O}_{91} \mathrm{H}_{21}$ at percentage of $6.66 \%$ and $3.33 \%$, ETEC were $\mathrm{O}_{125} \mathrm{H}_{21}$ and $\mathrm{O}_{124}$ at percentage of $6.66 \%$ and $3.33 \%$ (Table, 9). Also, EPEC $\mathrm{O}_{158}$ was isolated from $\mathrm{C}$ abattoir at percentage of $3.33 \%$, EHEC were $\mathrm{O}_{26} \mathrm{H}_{11}$, $\mathrm{O}_{91} \mathrm{H}_{21}$ and $\mathrm{O}_{111} \mathrm{H}_{2}$ at percentage of and 3.33, $3.33 \%$ and $6.66 \%$, ETEC was $\mathrm{O}_{128} \mathrm{H}_{172}$ at percentage of $3.33 \%$.

Table (3) indicated that Salmonella organisms were isolated from $6.66 \%, 23.33 \%$ and $13.33 \%$ for A, B and C. respectively. Salmonellae could be identified serologically as S. Infantis $3.33 \%$ S. Typhimurium $3.33 \%$ for A abattoir, S. Typhimurium 3.33\%. $S$. Enteritidis $10 \%$ S. Tsevie $3.33 \%$ S. Kentucky $3.33 \%$ S. Heidelberg $3.33 \%$ for B abattoir and S. Typhimurium $6.66 \%$ S. Enteritidis $3.33 \%$ and S. Tamale $(3.33 \%)$ for C abattoir with percentage of $6.66 \%$ for $\mathrm{A}$ abattoir, $23.33 \%$ for $\mathrm{B}$ abattoir and $3.33 \%$ for $\mathrm{C}$ abattoir.

Table (4) showed that $S$. aureus organism was isolated from $26.66 \%, 43.33 \%$ and $33.33 \%$ from A, B and C abattoirs, respectively with total no. of 31 and percentage of $34.44 \%$ of the three abattoirs. 
Table (1): average counts of Aerobic Plate (APC/g), Enterobacteriaceae and Staphylococci of the examined beef samples $(n=30)$

\begin{tabular}{lllll}
\hline $\begin{array}{c}\text { Abattoirs } \\
\text { Bacterial group }\end{array}$ & A & B & C \\
& & & \\
\hline APC & $1.33 \times 10^{7} \pm$ & $1.85 \times 10^{7} \pm 1.29 \times 10^{7} \pm$ \\
& $5.64 \times 10^{6}$ & $5.14 \times 10^{6}$ & $3.85 \times 10^{6}$ & \\
Enterobacteriaceae & $1.15 \times 10^{4} \pm 1.49 \times 10^{4} \pm 1.80 \times 10^{4} \pm$ \\
& $2.93 \times 10^{3}$ & $3.74 \times 10^{3}$ & $5.15 \times 10^{3}$ \\
Staphylococci & $1.75 \times 10^{4} \pm 2.19 \times 10^{4} \pm 2.31 \times 10^{4} \pm$ \\
& $4.91 \times 10^{3}$ & $5.82 \times 10^{3}$ & $5.74 \times 10^{3}$ & \\
& & & & \\
\hline
\end{tabular}

Table (2): Incidence and serotyping of Enteropathogenic E. coli isolated from the examined beef samples $(n=30)$.

\begin{tabular}{|c|c|c|c|c|c|c|c|}
\hline \multirow{2}{*}{$\begin{array}{l}\text { E. Coli } \\
\text { Strains }\end{array}$} & \multicolumn{2}{|c|}{ A } & \multicolumn{2}{|c|}{ B } & \multicolumn{2}{|l|}{$\mathrm{C}$} & \multirow{2}{*}{ Serotyping } \\
\hline & $\mathrm{Nc}$ & $\%$ & No. & $\%$ & No. & $\%$ & \\
\hline $\mathrm{O}_{26}: \mathrm{H}_{11}$ & 2 & 6.66 & 2 & 6.66 & 1 & 3.33 & EHEC \\
\hline $\mathrm{O}_{114}: \mathrm{H}_{4}$ & 1 & 3.33 & - & - & - & - & EPEC \\
\hline $\mathrm{O}_{172}$ & 1 & 3.33 & - & - & - & - & EPEC \\
\hline $\mathrm{O}_{128}: \mathrm{H}_{172}$ & 1 & 3.33 & - & - & 1 & 3.33 & ETEC \\
\hline $\mathrm{O}_{125}: \mathrm{H}_{21}$ & - & - & 2 & 6.66 & - & - & ETEC \\
\hline $\mathrm{O}_{163}: \mathrm{H}_{2}$ & - & - & 1 & 3.33 & - & - & EPEC \\
\hline $\mathrm{O}_{91}: \mathrm{H}_{21}$ & - & - & 1 & 3.33 & 1 & 3.33 & EHEC \\
\hline $\mathrm{O}_{78}$ & - & - & 1 & 3.33 & - & - & EPEC \\
\hline $\mathrm{O}_{124}$ & - & - & 1 & 3.33 & - & - & ETEC \\
\hline $\mathrm{O}_{111}: \mathrm{H}_{2}$ & - & - & - & - & 2 & 6.66 & EHEC \\
\hline $\mathrm{O}_{158}$ & - & - & - & - & 1 & 3.33 & EPEC \\
\hline Total & 5 & 16.66 & 8 & 26.66 & 6 & 20 & \\
\hline
\end{tabular}


Table (3): Incidence and serotyping of salmonella isolated from the examined beef samples $(\mathrm{n}=30)$.

\begin{tabular}{|c|c|c|c|c|c|c|c|c|c|}
\hline \multirow{2}{*}{$\begin{array}{c}\text { abattoirs } \\
\text { Salmonella }\end{array}$} & \multicolumn{2}{|c|}{ A } & \multicolumn{2}{|c|}{ B } & \multicolumn{2}{|c|}{$\mathrm{C}$} & \multirow[t]{2}{*}{ Group } & \multicolumn{2}{|c|}{$\begin{array}{l}\text { Antigenic } \\
\text { Srtucture }\end{array}$} \\
\hline & No. & $\%$ & No. & $\%$ & No. & $\%$ & & $\mathrm{O}$ & $\mathrm{H}$ \\
\hline S. Infantis & 1 & 3.33 & - & - & - & - & $\mathrm{C}_{1}$ & $6,7,14$ & $\mathrm{r}: 1,5$ \\
\hline S.Typhimurium & 1 & 3.33 & 1 & 3.33 & 2 & 6.66 & $\mathrm{~B}$ & $1,4,5,12$ & $\mathrm{i}: 1,2$ \\
\hline S. Enteritidis & - & - & 3 & 10 & 1 & 3.33 & $\mathrm{D}_{1}$ & $1,9,12$ & $\mathrm{~g}, \mathrm{~m}:$ \\
\hline S. Tsevie & - & - & 1 & 3.33 & - & - & $\mathrm{B}$ & 4,5 & i: e, n, $\mathrm{z}_{15}$ \\
\hline S. Kentucky & - & - & 1 & 3.33 & - & - & $\mathrm{C}_{3}$ & 8,20 & $\mathrm{i}: \mathrm{Z}_{6}$ \\
\hline S. Heidelberg & - & - & 1 & 3.33 & - & - & $\mathrm{B}$ & $4,5,12$ & $\mathrm{r}: 1,2$ \\
\hline S. Tamale & - & - & - & - & 1 & 3.33 & $\mathrm{C}_{3}$ & 8,20 & $\mathrm{Z}_{29}: \mathrm{e}, \mathrm{n}, \mathrm{z}_{15}$ \\
\hline Total & 2 & 6.66 & 7 & 23.3 & 4 & 13.3 & - & - & - \\
\hline
\end{tabular}

Table (4): Incidence and serotyping of Staphylococcus aureus isolated from the examined beef samples $(n=30)$.

\begin{tabular}{lcc}
\hline Abattoir & No. & $\%$ \\
\hline A & 8 & 26.67 \\
\hline B & 13 & 43.33 \\
\hline C & 10 & 33.33 \\
\hline Total $(90)$ & 31 & 34.44 \\
\hline
\end{tabular}

\section{DISCUSSION:}

A complete ignorance on the part of the meat handlers/ butchers in hygienic handling of carcasses during slaughter and retailing processes might be the main factors for producing meat with high microbial load. Hot and humid climate of this coastal area would have contributed in increasing the microbial load (Mukhopadhyay et al. 2009).

Lower aerobic Plate Count was recorded by El-Dally (1994) who studied that the mean value of total APC in shoulder muscle of beef was $4.7 \times 10^{3}$ Murray et al. (2001) who studied the mean value of total APC were 5.6 $\mathrm{x} 10^{2} \pm 0.44 \mathrm{x} 10 \mathrm{cfu} / \mathrm{g}$ and in beef carcasses.
El-Taher (2009) who noticed that, the mean value of APC was $8.17 \times 10^{4}$ in raw meat. Salama (2013) who examined that mean value of $\mathrm{APC} / \mathrm{g}$ of examined cattle meat samples from slaughterhouses of Elbagour, Menouf and Shibin-Elkoom were $1.92 \times 10^{5} \pm 0.36 \times$ $10^{5}, 8.58 \times 10^{4} \pm 2.01 \times 10^{4}$ and $3.14 \times 10^{4} \pm$ $0.69 \times 10^{4}$, respectively. Higher count was recorded by Paul and Sylvia (2014) who recorded that mean APC were $1.64 \times 10^{9} \mathrm{cfu} / \mathrm{g}$ for abattoir and $1.92 \times 10^{9} \mathrm{cfu} / \mathrm{g}$ for butcheries.

Enterobacteriaceae have an epidemiological importance as some of their members are pathogenic and may cause serious infections and food poisoning outbreaks to human being. Furthermore, the 
total Enterobacteriaceae count can be taken as indicator of possible enteric contamination in the absence of coliform organisms (Mosupye and Van Holy, 2000).

Lower total Enterobacteriaceae count was recorded by El-Dally (1994) who found that the mean value of total Enterobacteriaceae count in shoulder muscle of beef was 5.67 $\mathrm{x} 10^{2} \mathrm{cfu} / \mathrm{cm} 2$. Murray et al. (2001) who revealed that total Enterobacteriaceae counts were $0.11 \times 10 \pm$ $0.20 \mathrm{x} 10 \mathrm{cfu} / \mathrm{g}$ in beef carcasses. while higher count was recorded by Feizullah and Daskalov (2010) who revealed that the values of total Enterobacteriaceae count varied between $2 \times 10$ to $1.5 \times 10^{3} \mathrm{cfu} / \mathrm{cm} 2$ for the smaller factory and $1.9 \times 10$ to $1.1 \times 10^{6} \mathrm{cfu} / \mathrm{cm} 2$ for the high capacity slaughterhouse.

Staphylococcal food borne disease is one of the most common diseases worldwide resulting from the contamination of food by staphylococcus aureus enterotoxins. Although several SEs have been identified; SEA, a highly stable SE, is considered the most cause of SFD worldwide. Presence of pathogens in food products imposes potential hazard for consumers and cause grave economic loss and loss in human productivity via food borne disease. (Kadariya et al. 2014).

Lower count was recorded by by El-Taher (2009) who noticed that Staphylococci count were $4.16 \times 10^{3}$ for raw meat. Salama (2013) who revealed that mean value of Staphylococcal counts/g of examined meat samples from slaughterhouses of Elbagour, Menouf and Shibin-Elkom were $7.28 \times 10^{3} \pm$ $1.69 \times 10^{3}, 3.95 \times 10^{3} \pm 0.84 \times 10^{3} / \mathrm{g}$ and 1.07 $\times 10^{3} \pm 0.26 \times 10^{3}$, respectively.

Millions of people suffer from preventable food borne diseases every year. Food borne diseases are the growing public health problem and imply a great impact worldwide. Pathogenic E. coli are responsible for three major types of clinical infections like enteric and diarrheal diseases, urinary tract infections, sepsis and meningitis. (Maheux et al. 2009).

Actually, E. coli was previously isolated from fresh meat by El-Dally (1994) who said that E.coli was found in one sample, El-Taher (2009) E.coli were isolated from $20 \%$ from raw meat, , Salama (2013) who reported that E.coli from cattle meat samples from slaughterhouses of Elbagour (25\%), Menouf $(20 \%)$ and Shibin Elkom (10\%) and Enteropathogenic E.coli organisms were isolated from $30 \%, 20 \%$ and $15 \%$ of the examined samples of camel meat at Elbagour, Menouf, and Shibin Elkom abattoirs, respectively. , Abd El- Salam-azza (2014) revealed that E.coli species were recorded with lower percentages (12.8\%).

The presence of potentially pathogenic Salmonella serotypes at the slaughtering stages is an evidence of the circulation of this pathogen in the food environment; its presence could increase consumers' risks of infection if proper food handling and preparation techniques are not followed, (Narváez-Bravo et al., 2013).

Salmonella organisms were previously isolated from fresh meat by Majagaiya et al. (2008) who detected that a total of 250 raw meat samples for salmonella during September 2008 to December 2008 in Nepal. Salmonella was found to be positive in 23(9.2\%) of 250 examined samples, 4 samples of buffalo $(8.00 \%)$ were found to be positive for salmonella. Different salmonella spp. was isolated from different types of meat samples belonging to Sero group D and E., Salama (2013) who isolated Salmonella from cattle meat samples from slaughterhouses of Elbagour (25\%), Menouf (20\%) and Shibin 
Elkom (10\%) , Abd El- Salam-Azza (2014) who said that Salmonella species were recorded with lower percentages $(6 \%$,$) .$

Food intoxication caused by $S$. aureus occurred by eating food containing ready formed Staphylococcus enterotoxin produced by enterotoxin producing $S$. aureus, today there are over twenty types of enterotoxins has been discovered and differentiated into Staph. enterotoxin A to Staph. enterotoxin IV (Hennekinne et al. 2012).

S. aureus organism were previously isolated from fresh meat by El-Taher (2009) who said that $S$. aureus were isolated from $26.6 \%, 33.3 \%$ and $53.3 \%$ of raw meat, raw chicken meat and kofta. respectively, Datta et al. (2012) who isolated 35 of $S$. aureus and all these isolates were tested for their sensitivity against common antibiotics used in Bangladesh.

\section{CONCLUSION:}

One can have concluded from the achieved results in this study that the examined beef samples were contaminated with different types of bacteria at different Monifyea abattoirs (Shibin-Elkom, Ashmon, Menouf) Furthermore, the contamination of such examined samples may be acquired during slaughtering, handling as well as preparation of their carcasses.

\section{REFERENCES:}

Abd El- Salam, Azza S. (2014): "Molecular detection of antimicrobial resistance for some food borne pathogens". Ph. D. Thesis (Bacteriology, Mycology and Immunology) Fac. Vet. Med. Zagazig Univ.

APHA "American Public Health Association" (2001): Compendium of Methods for the Microbiological examination of Foods. $4^{\text {th }}$ Ed. F.P. Downes and K. Ito(editors), APHA. Washington D.C., USA.

Borch, E. and Arinder, P. (2002): Bacteriological safety issues in beef and Ready-to-eat meat products, as well as control measures. J. Meat Sci., 62(3): 381-390.

Datta, S. A., Akter, A., Shah, I. G., Fatema, K., Islam, T. H., Bandyopadhyay, A., Khan, Z. U. M. and Biswas, D. (2012): "Microbiological Quality Assessment of Raw Meat and Meat Products and Antibiotic Susceptibility of Isolated Staphylococcus aureus". J. Agric. Food Anal. Bacteriol., 2: 187195.

El-Dally, K.M.A. (1994): Correlation between parasitism and microbial load and meat quality of the Egyptian food animals. Ph D. (Meat Hygiene), Fac. Vet. Med. Moshtohor, Zagzig Univ.

Eley, A. R. (1992): Microbial food poisoning.1st Ed. P.46-51. Champan and Hall Publisher, London.

Egyptian organization standardization (EoS) (1522/2005): Egyptian Organization for specialization and quality control, Egyptian Standard for fresh meat. Ministry of Industry No. 1522/2005.

El-Taher-Amna, M. (2009): "Impact of temperature abuse on safety of food offered in a University Student Restaurant". M.V. Sc. Thesis, Meat Hygiene, Fac. of Vet. Med., Benha Univ.

Feizullah, F. and Daskalov, H. (2010): Investigation on lamb meat production hygiene in facilities with low and high production 
capacity.Bulg. J. Vet. Med., 13(4): 252-258.

Health Protection Agency - Corporate Plan 2004-2009. (April 2004). HPA (2004): Available from: http://www.hpa.org.uk/web/HPAweb File/HPAweb_C/1197021714519.

Hennekinne, J.; De Buyser, M. and Dragacci, S. (2012): Staphy. aureus and its food poisoning toxins: characterization and outbreak investigation. Federation of European Microbiological Societies Microbiology Reviews., 36(4): 815836.

International Commission and Microbiological Specification for Foods "ICMSF" (1996): Salmonellae. In: Roberts, T. A., Baird-Parker, A. C., and Tompkin, R. B. eds. Microorganisms infoods 5: Microbiological specifications of food pathogens. 1st Ed, Blackie Academic \& Professional, London, UK, 217-264.

ISO 6579 (2002): "Microbiology of food and animal feeding stuffs horizontal method for the detection of Salmonella spp". International standard. ( $4^{\text {th }}$ edition).

Kadariya, J.; Smith, T. C. and Thapaliya, D. (2014): Staphylococcus aureus and Staphylococcal food -borne Disease: An ongoing challenge in Public Health. Bio. Med. Res. Int., Article ID 827965, 9 pages. Kampala City, Uganda Int. J. F. S., 16: 29-35.

Maheux, A.F.; Picard, F.J.; Boissinot, M.; Bissonnette, L.; Paradis, S. and Bergeron, M.G. (2009): Analytical comparison of nine PCR primer sets designed to detect the presence of Escherichia coli/Shigella in water samples. Water Res., 43: 3019-3028.

Majagaiya, S. P.; Regmi, S.; Shah, K. and Manandhar, P. (2008): Isolation of salmonella species in different meat samples of Kathmandu valley. J. Nep. Associ. Med. Lab. Sci., 51-53.

Maturin, L.J. and Peeler, J.T. (1998): Aerobic plate count. Ch. 3. In Food and Drug Administration Bacteriological Analytical Manual, 8th Ed. (revision A), (CD-ROM version). R.L. Merker (Ed.). AOAC International, Gaithersburg, M.D.

Mosupye, F.M. and Van Holy, A. (2000): Microbiological hazard identification and exposure assessment of street food vending in Johannesburg, South Africa. Inter. J. Food Microbiol., 61(2-3): 137-145.

Mukhopadhyay, H.K.; Pillai, R.M.; Pal, U.K. and Kumar, V.JA.J. (2009): Microbial quality of fresh chevon and beef in retail outlets of Pondicherry. Tamilnadu J. Vet. Ani. Sci.,5 (1):3336.

Murray, K.A.; Gilmour, A. and Madden, R.H. (2001): Microbiological quality of chilled beef carcasses in Northern Ireland: a baseline survey. J. Food Prot., 64: 498 - 502.

Narváez, B.C.; Rodas, G. A.; Fuenmayor, Y.; Flores,R.C.; Carruyo, G.; Moreno, M.; Perozo,M. A. and Hoet, A.E. (2013): Salmonella on feces, hides and carcasses in beef slaughter facilities in Venezuela. Int. J. Food Microbiol., 166 (2):226-30. doi: 10.1016/j.ijfoodmicro. 2013.07.009. Epub 2013 Jul 17.

Paul,B. and Sylvia,A.B. (2014): Microbiological Quality of Meat at 
the Abattoir and Butchery Levels Int.

J. Food Microbiol., 164(7):152-70

Phillips, Jordan, D., Morris, S., Jenson,I. and Sumner, J.( 2006): A national survey of the microbiological quality of beef carcasses and frozen boneless beef in Australia. J. Food Prot., 69 (5): 11131117.

Pires, S. M.; Vieira, A. R.; Perez, E.; Wong, D. L. F. and Hald, T. (2012): Attributing human foodborne illness to food sources and water in Latin America and the Caribbean using data from outbreak investigations. Int. J. Food Microbiol., 152(3):129-38.

Salama, E. A. (2013): Sanitary conditions of cattle and camel carcasses at Menofia Abattoirs. Ph.D., Thesis (Meat Hygiene), Fac. Vet. Med. Benha Univ. 